\title{
Hubungan Usia Terhadap Presbiopi Pada Pengabdian Masyarakat di Tengah Pandemi Covid-19 JABODETABEK
}

\author{
Agoes Soedrajat ${ }^{*}$, Eriko Ruslan dan Sahel \\ Akademi Refraksi Optisi (ARO) Kartika Indera Persada, Gedung Indra Sentra Unit ap/ao Jl. Letjend \\ Suprapto no. 60 Cempaka Putih Jakarta Pusat 10520 \\ Correspondence: lpm.arokartika@gmail.com \\ Received: 30 Juni 2021 - Revised: 01 Agustus 2021 - Accepted: 16 Agustus 2021
}

\begin{abstract}
Abstrak. Bertambahnya usia tidak dapat dipungkiri, akan berkurangnya kemampuan menggunakan beragam teknologi dikarenakan mulai terbatasnya jarak penglihatan dengan jelas, hal ini diakibatkan dengan Semakin bertambah usia seseorang maka kemampuan Akomodasinya akan semakin berkurang. Makna kemampuan akomodasi di sini adalah kemampuan elastisitas mata untuk mencembung berkurang yang berakibat kepada kemampuan mata untuk melihat dekat berkurang. sesuai dengan hasil dari Program Pengabdian Masyarakat yang diadakan pada bulan Januari-Februari 2021, di tengah pandemi Covid-19 dalam wilayah JABODETABEK sesuai dengan domisili mahasiswa dengan kategori pemeriksaan siswa dan Guru. Untuk penelitian ini data yang digunakan adalah data guru berupa data usia dan hasil pemeriksaan Presbiopia. Untuk diketahui apakah ada hubungan antara Usia dengan Presbiopia, dan setelah dibuktikan dengan SPSS 26 uji korelasi non parametik dinyatakan bahwa adanya hubungan antara Usia dengan Presbiopia hal itu dikarenakan nilai sig $0.000<0,05$ dan mempunya hubungan yang sangat kuat antara Usia dan Presbiopia dibuktikan dengan nilai koefisien korelasi 0,867 .
\end{abstract}

Kata kunci: usia, presbiopia

Citation Format: Soedrajat, A, Ruslan, E \& Sahel. (2021). Hubungan Usia Terhadap Presbiopi Pada Pengabdian Masyarakat di Tengah Pandemi Covid-19 JABODETABEK. Prosiding Seminar Nasional Abdimas Ma Chung (SENAM), 15-22. 


\section{PENDAHULUAN}

Manusia sebagai makhluk hidup mengalami berbagai perubahan pada setiap organ tubuhnya, perubahan juga terjadi secara alami pada media refrakta manusia yaitu mata. Salah satu perubahan yang terjadi adalah perubahan kemampuan Akomodasi berbanding terbalik dengan pertambahan usia setia individu semakin. Semakin bertambah usia seseorang maka kemampuan Akomodasinya akan semakin berkurang. Makna kemampuan akomodasi disini adalah kemampuan elastisitas mata untuk mencembung berkurang yang berakibat kepada kemampuan mata untuk melihat dekat berkurang. Kondisi ini dapat dilihat pada gaya pasien saat melihat dekat biasanya penderita presbiopia cenderung untuk menjauhkan objek yang dibacanya, untuk mendapatkan titik dekat yang pas agar bacaan yang dibaca terlihat jelas, secara otomatis penderita cenderung untuk menegakkan punggungnya. Menurut (Wolffsohn et al., 2020) Presbiopia didefinisikan sebagai kemunduran penglihatan dekat yang disebabkan oleh bertambahnya usia, yang dialami lebih dari $80 \%$ usia 40 tahun atau lebih. Berdasarkan pendapat tersebut dapat ditarik kesimpulan secara alami, terjadinya presbiopia umumnya dimulai pada usia 40 tahun.

Kemampuan akomodasi berkurang secara kontinyu akibat berkurangnya elastisitas lensa yang disebabkan oleh perubahan komposisi kimiawi, dikenal dengan istilah presbiop yang diterapi dengan kacamata baca (Neal et al., 2016; Katz et al., 2003; Miller 2005) dalam (Congga, 2018) Berdasarkan definisi tersebut dapat dijelaskan secara sederhana bahwa presbiopia bukan kelainan refraksi. Presbiopia adalah kondisi alami yang dialami media refraksi seiring berjalannya penambahan usia seseorang. Menurut Marie Joan Therese D. Balgos,1 Veronica Vargas,1 dan Jorge L. (Balgos et al., 2018) presbiopia adalah hilangnya atau berkurangnya kemampuan akomodasi mata. Kondisi dari presbiopia merupakan proses fisiologi normal yang tidak dihindari oleh setia orang dewasa khususnya pada usia 40 tahun atau lebih. Presbiopia menjadi salah satu penyebab berkurangnya kualitas hidup seseorang, disebabkan penderita mengalami kesulitan untuk melihat dekat atau membaca, sehingga wajar jika penderita mengalami kendala dalam menyelesaikan tugas berhubungan dengan penglihatan dekat bila tidak menggunakan alat bantu rehabilitasi penglihatan berupa kacamata dengan menggunakan lensa Positif.

Sejalan dengan penelitian yang diadakan sebelumnya tentang kelainan refraksi diketahui bahwa Presbiopia muncul pada usia 40 tahun ke atas. Namun, dari hasil pengambilan data didapatkan presbiopia pada kelompok usia 18-39 tahun sebanyak 144 
kasus atau 4,8\% dimana 101 kasus pada wanita dan 43 kasus pada laki-laki.(Kalangi et al., 2016).

Dari latar belakang tersebut, dalam Program Pengabdian Masyarakat Akademi Refraksi Optisi Kartika Indera Persada ini mengadakan penelitian dengan pemeriksaan di tengah Pandemi Covid-19, dilaksanakan pada 2 (dua) bulan Januari-Februari 2021. Dikarenakan menghindari kerumunan dan memutus tali penyebaran Virus Corona, sehingga kami pihak institusi mengadakan program pengabdian masyarakat secara mandiri. Yaitu dengan memberikan instruksi kepada mahasiswa dengan pendampingan jarak jauh dari dosen pembimbing. Mahasiswa cukup memeriksa 20 orang yang terdiri dari 10 Guru dan 10 siswa. pada daerah atau wilayah terdekat dengan mahasiswa.

Program pengabdian masyarakat ini sesuai dengan peraturan Menteri Pendidikan dan Kebudayaan Republik Indonesia no 3 tahun 2020 tentang Standar Nasional Pendidikan Tinggi. Bab IV pasal 56 tentang Standar pengabdian kepada Masyarakat dan Bab III pasal 45 tentang Standar Penelitian. Sudah menjadi ketentuan dari setiap perguruan tinggi untuk melaksanakan Tridharma perguruan tinggi.

\section{MASALAH}

Masyarakat terutama guru dengan usia yang berorientasi pada 40 - 60 tahun sudah mengeluhkan akan sulitnya melihat dekat. Dengan sudut pandang yang semakin terbatas. Karena permasalahan ini kami mengidentifikasi gejala tersebut termasuk Presbiopia, berdasarkan hasil pemeriksaan mata.

\section{METODE PELAKSANAAN}

Pada penelitian ini, metode yang digunakan adalah dengan kuantitatif deskriptif menurut (Lapau, 2014) membagi kuantitatif deskriptif dengan tiga bagian yaitu deskriptif studi kasus, korelasi dan crossescional. Dalam hal ini penulis menggunakan korelasi. Dengan metode survey dengan memberikan angket dalam bentuk google formulir yang diisi pada saat proses pemeriksaan oleh mahasiswa kepada Guru, baik guru sekolah, les atau privat maupun guru TPA. Yang berdomisili terdekat dengan mahasiswa dikarenakan kondisi wabah covid-19. Yaitu wilayah Jakarta, Bogor, Depok, Tangerang dan Bekasi. Pemeriksaan mata dengan menggunakan snellen chart untuk skiring mata dan mengunakan trial lens untuk mengetahui Presbiopia. Populasi guru yang terdapat presbiopia berjumlah 
246 Guru. Untuk data yang diolah digunakan seluruh populasi, untuk mendapatkan hasil yang maksimal. Menggunakan uji Korelasi non parametik untuk mengetahui seberapa besar hubungan Usia terhadap Presbiopia.

\section{HASIL DAN PEMBAHASAN}

\section{Program Kegiatan}

Data yang diperoleh dari kegiatan Program Pengabdian Masyarakat merupakan data primer yang didapatkan langsung pada saat pelaksanaan kegiatan tersebut penelitian dengan menggunakan kuantitatif ini, berdasarkan apa yang terjadi antar proses dalam menjalani Program Pengabdian Masyarakat. Dalam mengambil suatu permasalahan yang ada, melalui data yang diolah dengan SPSS Versi 26.

\section{Pengelompokan data}

Berikut keterangan data yang sudah dikelompokkan berdasarkan usia dan hasil pemeriksaan mata presbiopia atau yang lebih dikenal dengan at atua.

Tabel 1. Pengelompokan Data

\begin{tabular}{|l|l|r|r|r|r|r|r|}
\hline \multicolumn{2}{|c}{} & \multicolumn{7}{|c|}{ USIA } \\
\cline { 2 - 9 } \multicolumn{2}{c|}{} & $\mathbf{4 0 - 4 5}$ & $\mathbf{4 6 - 5 0}$ & $\mathbf{5 1 - 5 5}$ & $\mathbf{5 6 - 6 0}$ & $\mathbf{6 1 - 6 5}$ & $\mathbf{6 6 - 7 1}$ \\
\hline presbiopia & 1.00 & 38 & 0 & 1 & 0 & 0 & 0 \\
\cline { 2 - 9 } & 1.25 & 29 & 3 & 0 & 0 & 0 & 0 \\
\cline { 2 - 9 } & 1.50 & 29 & 15 & 4 & 0 & 0 & 0 \\
\cline { 2 - 9 } & 1.75 & 4 & 23 & 4 & 1 & 0 & 1 \\
\cline { 2 - 9 } & 2.00 & 3 & 13 & 15 & 0 & 0 & 0 \\
\cline { 2 - 9 } & 2.25 & 1 & 4 & 10 & 6 & 3 & 0 \\
\cline { 2 - 9 } & 2.50 & 0 & 0 & 3 & 14 & 2 & 0 \\
\cline { 2 - 8 } & 2.75 & 0 & 0 & 1 & 2 & 2 & 1 \\
\cline { 2 - 8 } & 3.00 & 0 & 1 & 2 & 2 & 3 & 5 \\
\cline { 2 - 8 } & 3.75 & 0 & 1 & 0 & 0 & 0 & 0 \\
\hline \multicolumn{1}{|c|}{ Total } & & 104 & 60 & 40 & 25 & 10 & 7 \\
\hline
\end{tabular}




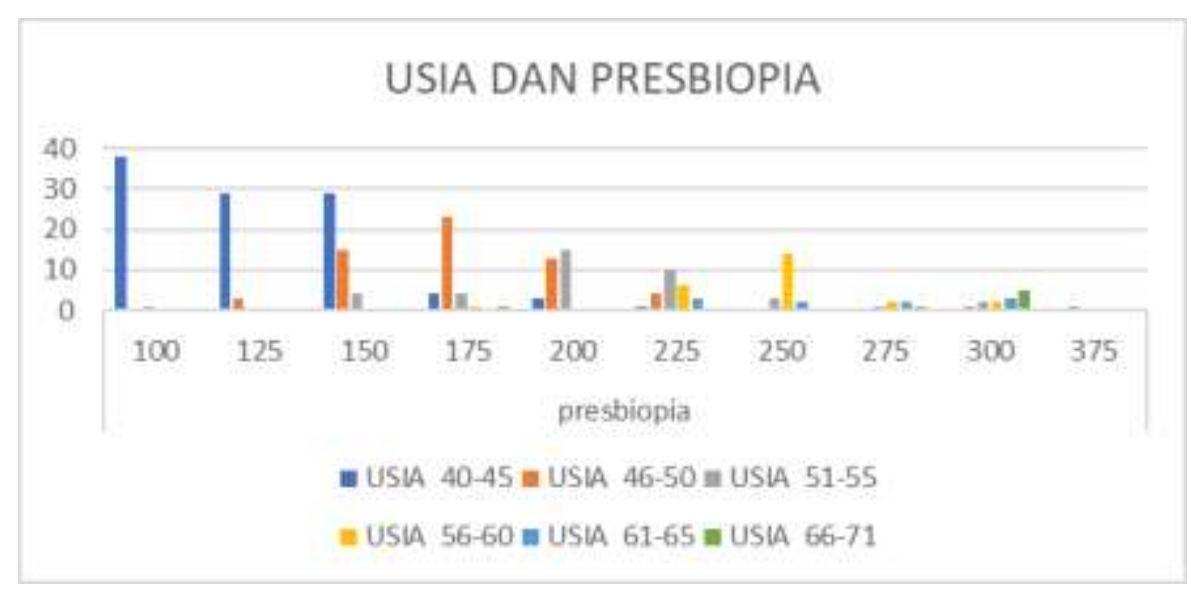

Gambar 1. Pengelompokan data

Dari data distribusi di atas, bahwa usia 40-45 bagian terbesar presbiopia 1.00 atau add. 1.00, usia 46-50 bagian terbesar pada presbiopia 1.75, usia 51-55 bagian terbesar pada presbiopia 2.00, usia 56 - 60 bagian terbesar pada 2.50, usia 61-65 bagian terbesar pada presbiopia 2.25 dan 3.00 dan usia $66-71$ bagian terbesar pada presbiopia 3.00. dari penggambaran distribusi data dapat terlihat dengan jelas bahwa adanya hubungan usia dengan presbiopia semakin usia bertambah semakin besar presbiopia.

\section{Uji Korelasi}

Untuk mengetahui apakah benar Usia mempunyai hubungan dengan Presbiopia, dibuktikan dengan uji korelasi chi square.

Tabel 2. Korelasi Usia dan Presbiopia

\begin{tabular}{|c|c|c|c|}
\hline \multicolumn{4}{|c|}{ Correlations } \\
\hline & & Usia & presbiopia \\
\hline \multirow[t]{3}{*}{ Usia } & $\begin{array}{l}\text { Pearson } \\
\text { Correlation }\end{array}$ & 1 & $.839^{* *}$ \\
\hline & Sig. (2-tailed) & & .000 \\
\hline & $N$ & 246 & 246 \\
\hline \multirow[t]{3}{*}{ presbiopia } & $\begin{array}{l}\text { Pearson } \\
\text { Correlation }\end{array}$ & $.839^{* *}$ & 1 \\
\hline & Sig. (2-tailed) & .000 & \\
\hline & $N$ & 246 & 247 \\
\hline
\end{tabular}


**. Correlation is significant at the 0.01 level (2-tailed).

Hipotesis:

Ho: Tidak terdapat hubungan antara Usia dengan Presbiopia

Ha: Terdapat hubungan antara Usia dengan Presbiopia

Dasar pengambilan Keputusan:

Ho diterima jika Sig $>0,05$

Ho ditolak jika Sig $<0,05$

Dari data diatas dinyatakan :

Ho : ditolak

Ha : diterima

Karena nilai sig. $0,000<0,05$.

Hal ini dapat disimpulkan bahwa ada hubungan antara Usia dan Presbiopia.

3. Koefisien Korelasi

Setelah diketahui adanya hubungan yang signifikan antara usia dan presbiopia maka dicari seberapa besar kekuatan hubungan yang terjadi, dengan koefisien korelasi. Berikut tabel koefisien Contingency untuk mengetahuinya.

Tabel 3. Koefisien Contingency

\begin{tabular}{|c|c|c|c|}
\hline \multicolumn{4}{|c|}{ Symmetric Measures } \\
\hline & & Value & $\begin{array}{l}\text { Approximate } \\
\text { Significance }\end{array}$ \\
\hline $\begin{array}{l}\text { Nominal by } \\
\text { Nominal }\end{array}$ & $\begin{array}{l}\text { Contingency } \\
\text { Coefficient }\end{array}$ & .867 & .000 \\
\hline \multicolumn{2}{|c|}{ Nof Valid Cases } & 246 & \\
\hline
\end{tabular}

Dari data di atas bisa dilihat bahwa koefisien korelasi sebesar 0,867. Ini berarti hubungan antara Usia dan Presbiopia sangat kuat. Sesuai ketentuan koefisien korelasi berpedoman pada Sugiyono (2019) dalam (Haryanti, 2021) sebagai berikut: 
Tabel 4. Koefisien Korelasi

\begin{tabular}{|l|l|}
\hline $0-0.199$ & Sangat rendah \\
\hline $0.20-0.399$ & Rendah \\
\hline $0.40-0.599$ & Cukup kuat \\
\hline $0.60-0.799$ & kuat \\
\hline $0.80-1.000$ & Sangat kuat \\
\hline
\end{tabular}

\section{KESIMPULAN}

Dalam penelitian berdasarkan hasil dari Program Pengabdian Masyarakat yang diadakan pada bulan Januari-Februari 2021, ditengah pandemic Covid-19 dalam wilayah JABODETABEK sesuai dengan domisili mahasiswa dengan kategori pemeriksaan siswa dan Guru. Untuk penelitian ini data yang digunakan adalah data guru berupa data usia dan hasil pemeriksaan Presbiopia. Untuk diketahui apakah ada hubungan antara Usia dengan Presbiopia, dan setelah dibuktikan dengan SPSS 26 uji korelasi non parametrik dinyatakan bahwa adanya hubungan antara Usia dengan Presbiopia hal itu dikarenakan nilai sig 0.000 $<0,05$ dan mempunya hubungan yang sangat kuat antara Usia dan Presbiopia dibuktikan dengan nilai koefisien korelasi 0,867 .

\section{UCAPAN TERIMA KASIH}

Ucapan terima kasih kepada segenap mahasiswa Angkatan 12, Dosen Pendamping dan semua pihak yang terlibat Akademi Refraksi Optisi Kartika Indera Persada, akan terlaksananya program pengabdian masyarakat di tengah pandemic Covid-19 hingga penelitian ini bisa diadakan.

\section{DAFTAR PUSTAKA}

Congga, O. (2018). Hubungan Presbiopia Terhadap Ketajaman Stereopsis Dekat Pada Kelainan Refraksi. 13.

http://digilib.unhas.ac.id/uploaded_files/temporary/DigitalCollection/ZDYxNzY3Mz Y0MmQ5NzNiZDQ1MjA0M2EyNWI4MGU3ZDVkOWQ1YjUxZQ==.pdf

Haryanti, S. (2021). Statistika Dasar Untuk Penelitian Jilid 1 Dengan Aplikasi SPSS: Pada bidang Pendidikan, Sosial dan Kesehatan. Media Sains Indonesia.

Kalangi, W., Rares, L., \& Sumual, V. (2016). Kelainan refraksi di poliklinik mata rsup prof. dr. r. d. kandou manado peKalangi, W., Rares, L. and Sumual, V. (2016) 'Kelainan refraksi di poliklinik mata rsup prof. dr. r. d. kandou manado periode juli 2014-juli 2016', 1(1), pp. 83-91.riode juli 2014-j. 1(1), 83-91. 
Lapau, B. (2014). Metode Penelitian Kesehatan; Metode Ilmiah Penulisan Skripsi, Tesis, dan Disertasi.

Balgos, M.J.T.D., Vargas, V. \& Alio, J.L.. (2018). Correction of presbyopia: An integrated update for the practical surgeon.

Wolffsohn, J. S., Leteneux-Pantais, C., Chiva-Razavi, S., Bentley, S., Johnson, C., Findley, A., Tolley, C., Arbuckle, R., Kommineni, J., \& Tyagi, N. (2020). Social Media Listening to Understand the Lived Experience of Presbyopia: Systematic Search and Content Analysis Study. Journal of Medical Internet Research, 22(9), e18306.

\section{(c) (i)}

(C) 2021 by authors. Content on this article is licensed under a Creative Commons Attribution 4.0 International license. (http://creativecommons.org/licenses/by/4.0/). 